\title{
Investigating the Relationship between Self-regularity Learning and Self-regularity among Iranian Students
}

\author{
Houri Aghajani \\ Educational Sciences \& Psychology, University of Isfahan \\ University of Isfahan, HezarJerib.st, Isfahan, Iran \\ Tel: 98-311-793-2128_E-mail: houriaghajani@yahoo.com \\ Halimeh Salehi (Corresponding author) \\ Educational Sciences, Khorasghan University \\ Jey .st, Arghavaniyeh, university .st, Iran \\ Tel: 98-311-535-4001Ｅ-mail: halimehsalehi@yahoo.com
}

Bibi Eshrat Zamani (Corresponding author)

Associate Professor, University of Isfahan

University of Isfahan, HezarJerib.st, Isfahan, Iran

Tel: 98-311-793-2128Ｅ-mail: nhdzamani@yahoo.com

Received: August 1, 2012 Accepted: September 23, 2012 Published: November 1, 2012

doi:10.5296/jse.v2i4.2181 URL: http://dx.doi.org/10.5296/jse.v2i4.2181

\begin{abstract}
The purpose of this study is to investigate the relation between self-directed learning and self-directed evaluation among the students of Esfahan Azad Universities in three different departments (Humanities, Basic Sciences and Technical Engineering). Results showed that in relation to the first research question, Coefficient of determination was 49.98 percent in Pearson test which showed 49.98 percent of variation in self-directed evaluation was explained by self-direct learning. While comparing gender differences indicated that mean score of female students was more than mean score of male students. About second question related to the field of study, results showed that in self -directed evaluation parameter, observed difference among mean score of the students with different fields of study was
\end{abstract}




\section{Macrothink}

Journal of Studies in Education ISSN 2162-6952 2012, Vol. 2, No. 4

significant while about self-regularity learning, observed difference among mean score of the students was not significant.

Keywords: Self-regulatory learning, Self-regulatory evaluation, Students, Isfahan, University 


\section{Introduction}

Self-regulatory activities are kind of activity in which students are beyond a passive listener or note taker. The student is allowed to forestall in some topics and teacher speaks less. Instead when working with other students to understand the course materials, s/he will led them to discover the information other than they can't discover it (Larnzn, 2004: 221).In other words self-regulatory is an approach in which the responsibility of creating or applying of knowledge is left for the students and its purpose is increasing learning rate. For simultaneous learning four factors should be considered: 1- Motivation; if students don't feel the necessity of acquiring that information, they won't master over the course and teacher's effort would be useless. 2- Reinforcement; Positive reinforcement will encourage good behavior and negative reinforcement will take away bad behavior. Reinforcement quarantines good behavior. 3- Transfer: transfer of learning is consequence of education and the ability to use learnt knowledge in new situations. Transmission occurs when learners are able to find a relationship between new knowledge and previously learnt knowledge.4- Retention: learners must keep information in mind so they can benefit from learning, to do this, they must interpret information to understand the meaning, interpret and apply it. Initial learning rate and the amount of exercise along learning affect retention (Ahmadvand, 2006:4).

Self-directed learning is an active process and processing structure through it a learner adjusts the purpose of his learning, cognition, motivation and behavior. (Nikoso et al., 2005). Research findings show that many of the learners who can adjust and control cognitive, motivational and behavioral aspects of their academic performance, have been too successful as a learner .these findings show that self-directed learning predicts academic achievements and in order to achieve academic success, learners should learn how to adjust their academic performance and keep their goals despite difficulty of learning materials. (Bembenutty, 2008).

Evaluation is related to products evaluation, regularizing process and learner person. (Samadi, 2001).Self-directed evaluation is a structure introduced by Bandura since 1960(Kadivar, 2001). Initial studies in this field were focused on self-directed evaluation base on general sense of the word that were proposed in different aspects of individual, social and family, since 1980 this structure is proposed in learning field and different psychological theories have considered it (Samadi 2004:81). Conducted studies about self-evaluator and non-self-evaluator people in different fields shows that these people are starter of the learning and determine achievable goals for themselves. Self-evaluator people review their performance and through "testing" strategy try to recognize their defects, amend and compensate them (Pintrich, 1986). Self-evaluator people use efficient strategies to achieve their goals and if needed will amend their strategies or will modify it. They are aware about how's and whys of using these strategies (Samadi, 2004:83).

According to the importance of this topic, this research is going to investigate the relationship between self-regulatory learning skill and self-regulatory evaluation among undereducated students of Isfahan Azad universities. 


\subsection{Learning}

According to the complexity of learning issue, different definitions are presented. The most famous definition is Kimball's definition of learning (1961). He believes that learning is a relatively permanent change in behavior or behavioral potential which acquires through experience and doesn't include temporary changes of body same as what happens due to the sickness, tiredness or drug (quoted Seif, 2007).

According to diversity of learning theories, the most comprehensive classifications which are closely associated with school learning Include: the theory of behaviorism, cognitive orientation and information processing, social learning and metacognition. In order to sum up the main points raised in four Predominated theories, following table is designed which contains four fundamental aspects of learning theory, Include emphasis areas, basic variables, theorists and theory applications (Abedi et al. 2005).

Table 1. introducing fundamental aspects of four learning theories proposed in the field of Educational Psychology (Abebi et al.2005)

\begin{tabular}{|c|c|c|c|c|}
\hline Application of theory & Theorists & Main variables & Emphasis points & approach \\
\hline $\begin{array}{l}\text { Presentation of learners strengthening } \\
\text { method and their effectiveness in the } \\
\text { learning process, Regulation and } \\
\text { distribution of knowledge and learning } \\
\text { control, teaching Step by Step Learning }\end{array}$ & $\begin{array}{l}\text { Watson, } \\
\text { Gatry, } \\
\text { Surndayk, } \\
\text { Skinner }\end{array}$ & $\begin{array}{l}\text { Stimulus, } \\
\text { response, } \\
\text { reinforcement, } \\
\text { punishment, } \\
\text { habits, } \\
\text { behavioral } \\
\text { objectives }\end{array}$ & behavior & 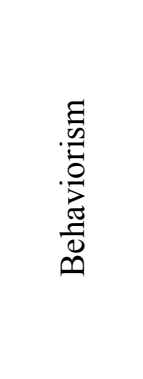 \\
\hline $\begin{array}{l}\text { Elaborating evolution of learners } \\
\text { understanding and their function in } \\
\text { training, Demonstrating the importance of } \\
\text { meaningful learning and Methods of } \\
\text { organizing learners mind and its getting } \\
\text { organized method }\end{array}$ & $\begin{array}{l}\text { Azuall, } \\
\text { Brunr, } \\
\text { Piaget, Gestalt }\end{array}$ & $\begin{array}{l}\text { Vision, } \\
\text { insight, } \\
\text { morphology, } \\
\text { recognition, } \\
\text { perception, } \\
\text { information } \\
\text { processing, } \\
\text { memory }\end{array}$ & cognition & 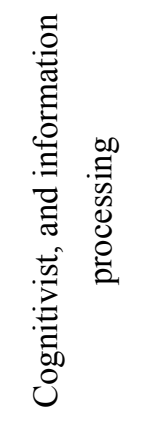 \\
\hline $\begin{array}{l}\text { Learning through observation, learning } \\
\text { through neighborhood, teach methods of } \\
\text { learning skills and attitude to learners }\end{array}$ & Bandura & & $\begin{array}{l}\text { behavior and } \\
\text { internal events }\end{array}$ & 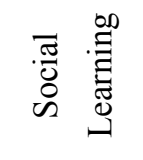 \\
\hline $\begin{array}{l}\text { Emphasize Self-discovery, self-starter, } \\
\text { self-evaluator learners, personal } \\
\text { organization of cognitive systems by } \\
\text { learner, learning based on learners' } \\
\text { cognitive strategies }\end{array}$ & Flavel & $\begin{array}{l}\text { self-control and } \\
\text { self-knowledge } \\
\text { cognitive system }\end{array}$ & $\begin{array}{l}\text { Metacognitive } \\
\text { processes }\end{array}$ & 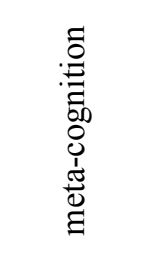 \\
\hline
\end{tabular}




\section{Macrothink}

Numerous factors and conditions can affect learning process; here are some conditions that affect learning:

1. Learning motivation: learning is a work same as many other activities and in some cases it's a difficult work but every hard work can be easy if done motivated and enthusiastically. Generally every encouraging behavior which leads to learner success would reinforce his/her motivation.

2. Awareness of inadequate current knowledge and skills: A learner should be aware of his inadequate current knowledge and skills. Experience has shown that usually when people identify the necessity of learning new knowledge or skills, willingly accept it.

3. Having a clear notion of the knowledge and skills that must be achieved: If a learner knows that learning these new things will lead him to what kinds of knowledge and skill, his/her learning would be purposeful.

4. Having enough time for exercise: obviously, acquiring each kind of knowledge and skill needs training, therefore its need that teachers consider enough time and suitable condition for exercise.

5. Knowledge of progress: This means that learner must be constantly reminded of his progress in lessons. Experience has shown that awareness of positive results during learning has a positive effect on learners' improvement and progress.

6. Having proper tools and resources for learning: Each subject according to its nature has tools and resources that can facilitate learning process (Safavi, 2001: 35-34).

Some effective factors in learning from Dr. Shariatmadari point of view:

1. Preparedness: In order to learn, learner should be completely prepared. We mean having sufficient growth in various fields by preparedness.

2. Previous experiences: previous experiences are base for understanding, insight and learning. Preparedness is affected greatly by previous experiences. Previous experiences help people to dealing with environment and getting compatible with it.

3. Learning situation: learning situation is used in two different meanings, sometimes it refers to parameters and conditions which affect learning process and other times refers to problems a person may face with.

4. Learner activities: some people consider learning activity a substantial need for learners and believe that individual's desire to physical movement, curiosity, and analyzing the environment are due to this idea while others believe that learning is an activity and its implementation does not occur without activity and its learning process that makes a person to work.

5. Stimuli: same as other forms of behavior, learning is result of stimuli or stimulus and as we suppose substantial needs as origin of individual's behavior, we suppose substantial needs as stimuli of learning. 
6. Using or transferring learned materials: Using scientific materials and applying them, dealing with problems, is called content transfer .In other words, using learned issues from one situation in another situation is called transfer.

7. Whole-part relations: learning begins from whole but with analyzing and combining, one not only gets familiar with components but also comprehends components relations. Understanding components relations and with the whole subject is essential for learning

8. Comprehension and insight: comprehension is basis of learning and in psychological terms it is, understanding relations among components and each of components relation with whole (Shariatmadari 2007: 118-112).

\subsection{Self-directed learning (self-regulatory)}

Self-regulatory is a structure that was introduced by Bandura in 1960(Kadivar, 2001). Initial studies focused on self-regulation in general sense of the word that proposed in various fields of personal, familial and social issue. Since 1980 this structure appeared in learning contexts and considered by various psychological theories such as behaviorism, cognitivist and constructivism. Common feature of all of these various viewpoints regarding this structure is relatively large overlap of these theories. All these theories have introduced cognitive and metacognitive strategies as the main core of self-regulatory structure (Purdy and Haty, 1996 quoting Samadi, 2004: 81). Researchers acknowledge that self-regulatory or Self-directed learning concept has aroused from existentialism view point that encourages individual liberty, responsibility and personal viewpoints.

By self-regulatory we mean that learners have skills for designing, controlling and directing their learning and tend to analyze whole process of learning and evaluate it (Kjbaf et al. 2003). Self-regulatory Learning is an important issue in human learning and Educational Psychologists emphasize on active participation in the learning process rather than passive learning experiences (Ao Man - Chih,2006). Self-regulatory learning is an active process and processing structure that through it learner controls and regulates his own learning activity objectives, knowledge, motivation and behavior (Nikos and George, 2005).

Main framework of self-regulatory theory is this that How learners use their metacognitive beliefs, motivation and learning behavior (Linen brink and Pentyrch, 2002). Self-directed learning includes active participation and purposeful behavior .Self-regulatory or self-directed learning about Activation of metacognitive skills exists in all levels of performing the activity (goal setting, planning and evaluating activities). In self-directed learning, its learner who defines learning activity always. A good learner should be able to explain what he needs to teach (Sofie et al., 2008). Self-directed learning is a broad phrase that includes various processes in most tangible form, it is a special kind of learning that can be differentiated from outside controlled learning. This means that learners have control over their learning and can control their cognition, perception and motivation to achieve specific learning objective. Self-directed learning involves student's more control over learning environment and considers an important role for learner at the beginning of his activity.

Self-directed learning can be examined from different aspects. For example it can be 
measured from voluntary, cognitive and socio-cultural aspects. Nevertheless four main elements should be mentioned in self-directed learning and theories. First, self-directed learning includes active participation of learner and during this process learner determines his goals and reviews his thoughts and emotions and modifies and adjusts them if needed. Second, self-directed learning models start from this point that learners have the ability to manage their learning and determine its goals (they control it). Self-directed learning acts at the frontiers of biological, developmental, situational and personal pervasively but, learners can be trained to develop their metacognitive knowledge and get better self-directed students. Third, learning behavior is goal-oriented and not random and forth, self-directed learning is a mediator variable among personal and situational variables, in order to achieve success (Ainley \& Patrick, 2004 and Boekaaerts \& Corno, 2005).

Performed studies about self-regulated people show that they are spontaneous in learning; set realistic educational goals for themselves; They use efficient strategies to achieve their goals and, if necessary, amend or change their strategies and try to make optimal use of available resources such as time, location, peers, parents, teachers and resources such as film, video and computer and always try to build, create and choose environments that improves learning (Samadi 2004: 160).

Self-regulation theories of learning consider that how students activate their learning process personally (Khademi and Noshad, 2006: 66). Self-regulatory learning can explain individual differences during acquiring skills. Successful learner shows self- regulatory adapted learning strategies and motivational patterns during doing assignments(for example striving for success, enjoy challenging work, proper use of learning strategies, setting specific goals and showing a high level of self-efficacy). On the contrary unsuccessful learners strive less and are not interested in doing activities. They are not able to set specific goals and learning strategy. They has low self-efficiency and rarely reaches a high level of success (Bmbvty, 2008). Generally Self-directed learning behaviors related to self-directed learning can be categorized into two groups: (1) behavioral, (2) cognitive. Behavioral or self-management activities, include motivation, will or authority (desire or decide), time management and continuing effort. Cognitive activity also includes mental processes of selection, expanding or describing, organizing, supervising or processing information from different aspects. Table (2-2) shows Self-directed learning categories or classes related to self-learning management.

Table 2. Self-directed learning categories, behavioral activities (self-management)

\begin{tabular}{|l|l|}
\hline $\begin{array}{l}1 \text { - time Detection } 2 \text { - Keep spent time effect } 3 \text {-suitable Timetable } 4 \text {-allocating time } \\
\text { according to homework }\end{array}$ & $\begin{array}{l}\text { Time } \\
\text { management }\end{array}$ \\
\hline $\begin{array}{l}\text { 1- Developing a creative learning environment } 2 \text { - adjusting learning and progress goals } 3 \text { - } \\
\text { start working } 4 \text { - finding curriculum materials 5 - Continuing effort }\end{array}$ & $\begin{array}{l}\text { Effort } \\
\text { management }\end{array}$ \\
\hline $\begin{array}{l}\text { 1- careful study } 2 \text { - to investigate weak and strong points of study habits } 3 \text { - tracing time and } \\
\text { activities and attempt management }\end{array}$ & $\begin{array}{l}\text { Motivation } \\
\text { or will }\end{array}$ \\
\hline
\end{tabular}


Table 3. Self-directed learning categories: cognitive activities

\begin{tabular}{|l|l|}
\hline Sample activities & category \\
\hline $\begin{array}{l}\text { 1-finding necessary information and discard unnecessary information } \\
\text { 2-summarize educational materials3-highlighting important issues }\end{array}$ & selection \\
\hline Overall review and considering all previous information and materials & perception \\
\hline 1- Review. 2. Reminder test. 3 -self-test exams 4.devise appropriate strategies for study & $\begin{array}{l}\text { Memory } \\
\text { boosters }\end{array}$ \\
\hline $\begin{array}{l}\text { 1-self-question. 2.-illustration. 3- metaphors and analogies } \\
\text { 1.Paraphrase. 2 .Communicative assistance (maps and charts and time lines). 3-using related } \\
\text { and multiple sources 4-using previous knowledge } \\
\text { 5.Provide a response beyond current requirements and needs }\end{array}$ & $\begin{array}{l}\text { Describe and } \\
\text { explain } \\
\text { (Expand) }\end{array}$ \\
\hline $\begin{array}{l}\text { 1-identifying what you are not master in 2-awareness of weak and strong points } \\
\text { Integration }\end{array}$ \\
\hline
\end{tabular}

Source: (Nadi and Kazemi, 2005: 126-125).

\subsection{Evaluation}

It's an important fact that all human being marvelous progress in today's life originates from learning. Since factors that affect learning are too varied, identifying these factors is important to remove problems and failures of educational system that one of these factors is evaluation (Sarchmy and Hosseini, 2004: 65). Higher education as a system is looking for goals and surely achieving to these goals will be practicable just when components and the whole system be evaluated any time (Rhbarda, 2005). Undoubtedly evaluation is one of the most effective methods to warrant quality and also is essential for continuous improvement in educational system. Evaluation of the literature shows that approximately definitions of evaluation are as much as the number of scientists who work in this field. Here some of these definitions are briefly discussed. Evaluation is the use of search methods and judgment, include setting standards in order to judge quantity, decision-making and collecting related information and to apply these standards to determine value, quality, usefulness and effectiveness of program or organization (Fitzpatrick et al., 2004). Evaluation is a systematic process for collecting and interpreting data that determines the realization of desired goals (Seif, 2003: 25). Gibbs \& Simpson declare that evaluation has an enormous effect on learning, what that learner concentrates on, amount of studying time, quality of Participating in learning activities, feedbacks and understanding of learning . Patvn considers evaluation as collecting data about activities, programs specifications and outputs in order to judge about the program, Improve the effectiveness of programs or informing for future planning (Quoting Bazargan, 2009: 20).

Evaluation means testing and judging value, quality, importance, degree or conditions of a phenomenon. From activity point of view, evaluation is an operation that can find out the 
result of program through it and obtain the reasons of success or failure of program and got aware of program presenting method. Collecting and using information for decision making is a very precise and technical issue, if done correctly, then will be effective. Although should acknowledge to its complexity and delicacy, due to this complexity, never can present a comprehensive definition for it (Sheikhi, 2004: 42).

\subsection{Self-directed evaluation (self-evaluation)}

Location of Control refers to the circumstance of controlling environment. It is a system of believes that one evaluates his/her success and failure according to. Those who believe that their destiny is at control of themselves have inner source and those who believe that their destiny is controlled by external factors have external source (Ratr, 1966 quoted from Shahrara and Soleyman Nejad, 2001: 176).

Control resource can be explained by a continuum that describes a man's responsibility in controlling attempts. Two ends of this continuum are: self-control (internal control) and external control.

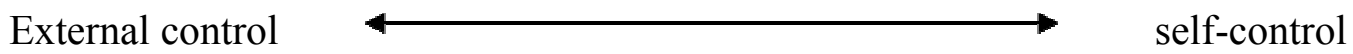

In one end of continuum, origin of control is situated out of the Person that is called external source and in such circumstances behavior is due to environmental factors. According to this viewpoint researchers and psychologists emphasize on favorable impact of external control on man behavior. In other side of this continuum the source of control is self-induced. Here man plays an active role both mentally and practically in control process. People can play a role in determining standards, evaluation of performance and improvement of results objectively and can create a mental atmosphere or external reality so that they can manage their behavior in specific situations subjectively (Amir, 2004: 73-72). Self-directed evaluation is used by self-control people more. Self-directed is a system that makes students develop some criterion for themselves and then they can judge how much they have been successful to achieve these criterion (Kenen \& neiuble).

An effective evaluation includes removing uncertainty in analyze and existence of clear goals to evaluating man performance. Theoretical basis of self-evaluation is Bandura's social cognitive theory. According to this theory, those who have self-determined goals and supervise implementation of these goals themselves, autonomous people, are much more efficient and effective than others. On the other hand, self-evaluation is an appropriate index to predict the behavior. When people are in high levels of self- consciousness, this selfconsciousness helps them to see themselves through others' eyes and evaluate themselves 
according to this opinions and ultimately this leads them to an accurate and appropriate self-evaluation (Sarmadi and Seif, 2008: 136-135).

\subsection{Background of research abroad of country (Iran)}

Research findings by Pentrich \& Zusho (2007) (quoting Bembenutty, 2008) demonstrated that many of people who have been able to control cognitive, motivational, and behavioral aspects of their academic performance have been very successful, as a learner. Also self-regulation learning is predictor of academic performance. To achieve academic success, Learners should learn how to regulate their performance and keep their goals despite difficulty of homework. Results of a survey by Charlotte and colleagues (2008) demonstrated that Self-directed learning strategies have an effective role on students' success.

Langendyk surveyed the role of self-cognitive leaning. Third-year students of medical in a problem-oriented program were evaluated. Students were asked to evaluate their sheet and a sheet from one of their classmate. In this regard correct answers and scoring criteria created. In addition teachers marked sheets too. Relationship between marks that students gave to themselves and marks that students gave to classmates surveyed. Weak students had marked themselves and other students generously while strong students marked sheets stricter than teachers. Marks given by strong students were true too. Consequently we came to this point that about one third of the students have had this ability to evaluate classmates and themselves correctly and weak students mark giving was incorrect.

Faye Marsha (2006) in his research find out that many of the learners who can control their cognitive and motivational aspects have been successful students and this shows that self-regulatory can predict academic performance.

\subsection{Background of research inside the country (Iran)}

Samadi (2008), in his research entitled "investigating immediate and long term effects of teaching self-regulatory strategies on self-regulation and mathematical problem solving" which Aimed to investigate short and long term effects of self-regulatory strategies on self-regularisation of learners and their performance in mathematical problem solving, concluded that after training there is a significant difference in self-regulation strategies and mathematical problem solving ability in treated group. Treated group preserved its superiority even after one month in both self-regulatory strategies and mathematical problem solving. They also showed that self-regulatory strategies are learnable and teachable and if taught properly it would have stable effects.

Amini (2008) in his research titled "relation of self-regulatory learning strategies and motivational beliefs with academic progress of students "found out that self-regulatory learning strategies are associated with academic progress and all components of self-regulatory have the ability to predict learning progress.

\section{Research Method}

This is a practical research and correlation-descriptive method is used to perform it. 


\subsection{Populations}

Population of this research includes students of Isfahan Azad University in Humanities, Basic Sciences and technical-engineering categories (academic year 2011-2012). Treated population is consisted of items listed in Table (4)

Table 4: Number of students in each of Literature and Humanities, Science and Engineering categories

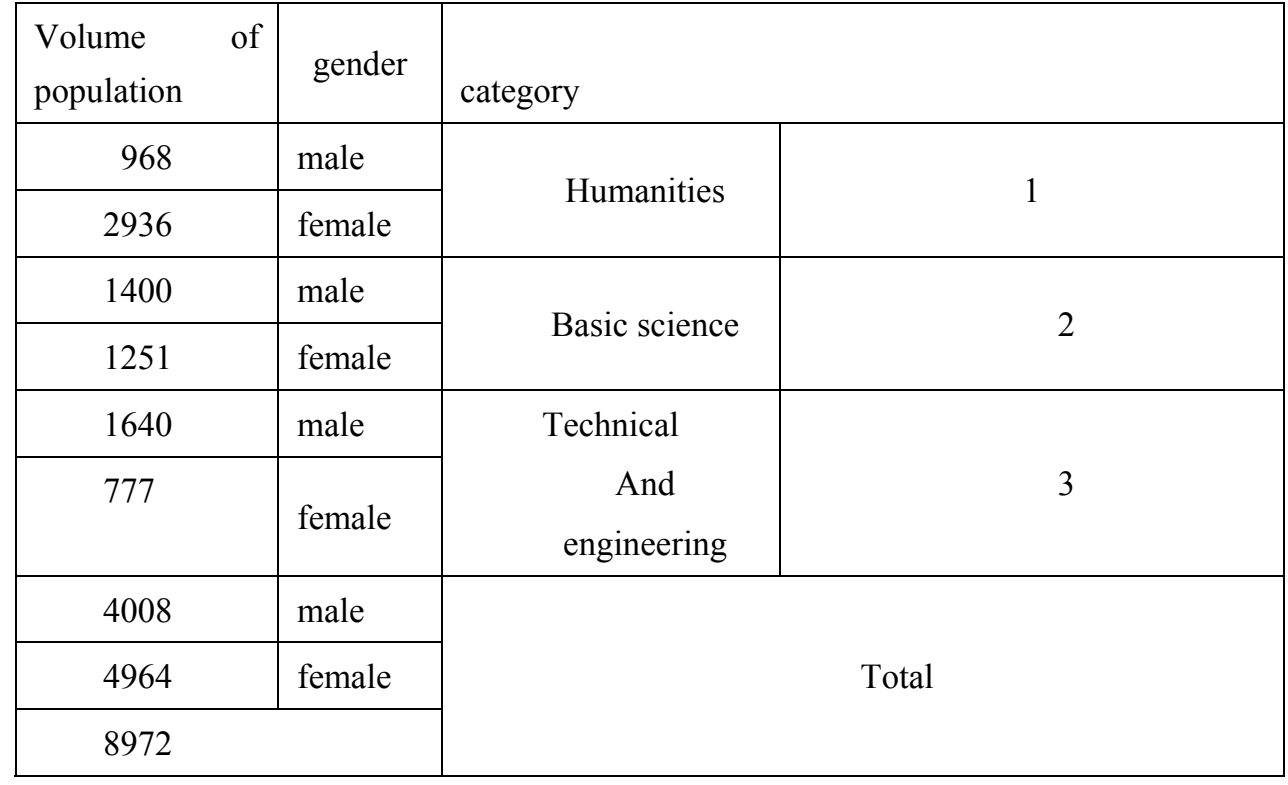

\subsection{Sampling method}

The method of sampling in this research is stratified sampling proportionate to the population size. Choosing this method is in order that the proportion of subgroups in population and sample be observed.

\section{3 determining sample size}

In order to determine sample size, after conducting preliminary questioner and calculating the variance, using Cochran's sample size formula, 367 students were selected as sample.

\subsection{Objectives and research questions}

Determining relationship between self-regulatory learning of students with their self-regulatory academic activities

Determining aforementioned relations according to demographic parameters, gender and field of study (Humanities, Basic Sciences, engineering)

Based on these objectives research questions are as follows:

Is there any relation between self-regulatory learning and self-regulatory evaluation?

According to aforementioned relations are demographic parameters (gender, field of study: 
Humanities, Basic Sciences, engineering) different?

\subsection{Data collection}

In this research, in order to collect the data a tailored questioner is designed by researcher. Also background and theoretical basis of this research are collected through reading books, papers, magazines and online databases. In this study, a field research is conducted and a tailored questionnaire is used for data collection. In order to design this questioner, similar questionaries' and research theoretical basics have been helpful.

\subsection{Components of constructed questionnaire}

Mentioned questionnaire contains two parameters and a total of 40 questions. First parameter (Self-directed learning), has 20 questions and second parameter (Self-directed Evaluation), has 20 questions. And two demographic factors include gender and field of study are mentioned at the end of questionnaire.

Since each of research parameters include some quotations Therefore, in order to measure these parameters, a continuum with 5 options is used, number 5 shows highest level of agreement and number 1 shows a minimum amount of agreement. People were asked to reply to questions with 1 to 5 numbers.

Table 5. constructed questioner with 5 options

\begin{tabular}{|c|c|c|c|c|}
\hline Never & rarely & Some times & often & Always \\
\hline 1 & 2 & 3 & 4 & 5 \\
\hline
\end{tabular}

In this continuum each option has a specific Rate Code that analyze will be done according to it.

\subsection{Questioner Validity}

In order to assess the validity of questioner, a preliminary questioner was designed and more confidence this tailored questioner was handed out to some of postgraduate students and psychology practitioners and their comments about Transparency of questions were surveyed. At the end after amending the questioner according to university professors' opinion, final format of questioner including 20 questions was prepared.

\subsection{Questioner reliability}

There are different methods to measure validity. In this study Cronboakh Alpha Coefficient is used to determine reliability. Above mentioned questioner was distributed among 30 people of research population. Then Cronboakh Alpha Coefficient through SPSS 17 software was calculated that 0.90 obtained.

\section{Analysis of Result}

In this chapter the collected data according to research questioner have been described and analyzed. 
3.1 first question: Is there any relationship between self-regulatory of students and their self-evaluation?

In order to achieve to the answer of this hypothesis, 40 items are included in this questioner. These items include two parameters (1-self-directed learning, 2-self-directed evaluation).In order to analyzing the relations, Person and spearman confidence tests are used. Results are presented in table 6 .

Table 6. results of self-directed learning and self-directed evaluation according to Pearson coefficient test

\begin{tabular}{|c|c|c|c|c|}
\hline $\begin{array}{c}\text { coefficient of } \\
\text { determination } \\
(\mathrm{r} 2) \%\end{array}$ & $\begin{array}{c}\text { Pearson Correlation } \\
\text { Coefficient }\end{array}$ & $\begin{array}{c}\text { sigma significance } \\
\text { level }\end{array}$ & frequency & $\alpha$ \\
\hline 49.98 & 0.707 & 0.000 & 250 & $0 / 01$ \\
\hline
\end{tabular}

Table (6) shows that Correlations between Self-directed learning and Self-directed evaluation is significant. In other words, there is significance correlation between self-directed learning of students and their self-directed evaluation in academic departments (Humanities, Basic Sciences and technical-engineering) of Isfahan Azad Universities. Correlation Coefficient is 0.707 that shows almost a high correlation. Coefficient of determination is \%49.98 that shows \%49.98 of self-directed evaluation changes can be justified through self-directed learning. For further confidence this question was studied by Spearman rank correlation test.

Table 7. results of self-directed learning and self-directed evaluation according to Spearman coefficient test.

\begin{tabular}{|c|c|c|c|c|}
\hline $\begin{array}{c}\text { coefficient of } \\
\text { determination } \\
(\mathrm{r} 2) \%\end{array}$ & $\begin{array}{c}\text { Pearson Correlation } \\
\text { Coefficient }\end{array}$ & $\begin{array}{c}\text { sigma significance } \\
\text { level }\end{array}$ & frequency & $\alpha$ \\
\hline 44.62 & 0.668 & 0.000 & 250 & $0 / 01$ \\
\hline
\end{tabular}

Table (7) shows that Correlations between Self-directed learning and Self-directed evaluation is significant. In other words, there is significance correlation between self-directed learning of students and their self-directed evaluation in academic departments (Humanities, Basic Sciences and technical-engineering) of Isfahan Azad Universities. Correlation Coefficient is 0.707 that shows almost a high correlation. Coefficient of determination is $\% 44.62$ that shows \%44.62 of self-directed evaluation changes can be justified through self-directed learning.

3.2 Second question -are aforementioned relations different according to demographic factors (gender and field of study: Humanities, Basic Sciences, engineering)? In continuation of this study gender and field of study will be surveyed respectively.

3.2.1 Gender: since gender is a dichotomous variable, comparison of two means tests (t-test) will be used. 


\section{Macrothink}

Table 8. Independent t-test results for gender variable

\begin{tabular}{|c|c|c|c|c|c|c|}
\hline \multicolumn{3}{|c|}{ t-test(equality of means) } & \multicolumn{2}{|c|}{$\begin{array}{c}\text { Levine's Test (Equality of } \\
\text { Variances) }\end{array}$} & \multirow{2}{*}{\multicolumn{2}{|c|}{ Components test }} \\
\hline $\begin{array}{c}\text { Sig } \\
\text { (2-taild) }\end{array}$ & $\mathrm{df}$ & $\mathrm{t}$ & Sig & $\mathrm{F}$ & & \\
\hline \multirow[t]{2}{*}{ 0/009 } & 248 & $-2 / 631$ & \multirow{2}{*}{$0 / 125$} & \multirow{2}{*}{$2 / 37$} & $\begin{array}{l}\text { Assuming equal } \\
\text { variances }\end{array}$ & \multirow{2}{*}{$\begin{array}{l}\text { Self-directed } \\
\text { learning }\end{array}$} \\
\hline & & & & & $\begin{array}{l}\text { Assuming unequal } \\
\text { variances }\end{array}$ & \\
\hline \multirow[t]{2}{*}{$0 / 005$} & 248 & $2 / 849$ & \multirow{2}{*}{$0 / 438$} & \multirow{2}{*}{$0 / 603$} & $\begin{array}{l}\text { Assuming equal } \\
\text { variances }\end{array}$ & \multirow{2}{*}{$\begin{array}{l}\text { Self-directed } \\
\text { evaluation }\end{array}$} \\
\hline & & & & & $\begin{array}{l}\text { Assuming unequal } \\
\text { variances }\end{array}$ & \\
\hline 0/009 & 248 & $2 / 634$ & $0 / 563$ & 2/973 & $\begin{array}{l}\text { Assuming equal } \\
\text { variances }\end{array}$ & total \\
\hline
\end{tabular}

Table 8 shows the results of these two tests. In one part Levine's tests for equality of variances is presented. In the second part the equality of the mean for both equal and unequal variance is presented. According to the results of table (8) equality of variances is assumed for all components. Since all components have significance level greater than 0.05 , then can say that variances are equal and therefore filling second row is avoided. Also about self-directed learning and Self-directed evaluation according to table (8) observed differences between male and female mean scores are significant, because Level of significance is less than 0.05. Namely male and female students have not offered same comments, mean scores of female students are more than mean scores of male students and about interactive skills observed differences between mean scores of male and female students are no significant, because Level of significance is more than 0.05 . 


\subsubsection{Field of study}

Table 9. The results of ANOVA analysis for field of study variable

\begin{tabular}{|c|c|c|c|c|c|c|}
\hline Sig & $\mathrm{F}$ & mean of & df & sum of squares & \multicolumn{2}{|c|}{ Source of component change } \\
\hline \multirow{3}{*}{0.127} & \multirow{3}{*}{2.082} & 0.467 & 2 & 0.934 & $\begin{array}{l}\text { Between } \\
\text { groups }\end{array}$ & \multirow{3}{*}{ Self-directed learning } \\
\hline & & \multirow[t]{2}{*}{0.224} & 247 & 55.369 & $\begin{array}{l}\text { Within } \\
\text { groups }\end{array}$ & \\
\hline & & & 249 & 56.302 & Total & \\
\hline \multirow{3}{*}{0.038} & \multirow{3}{*}{3.305} & 0.988 & 2 & 1.976 & $\begin{array}{c}\text { Between } \\
\text { groups }\end{array}$ & \multirow{3}{*}{ Self-directed evaluation } \\
\hline & & \multirow[t]{2}{*}{0.299} & 247 & 73.844 & $\begin{array}{l}\text { Within } \\
\text { groups }\end{array}$ & \\
\hline & & & 249 & 75.821 & Total & \\
\hline \multirow{3}{*}{0.158} & \multirow{3}{*}{1.0859} & 0.339 & 2 & 2.91 & $\begin{array}{l}\text { Between } \\
\text { groups }\end{array}$ & \multirow{3}{*}{ Total } \\
\hline & & \multirow[t]{2}{*}{0.182} & 247 & 129.213 & $\begin{array}{l}\text { Within } \\
\text { groups }\end{array}$ & \\
\hline & & & 249 & 132.123 & Total & \\
\hline
\end{tabular}

According to table (9) about self-directed evaluation component, observed difference between mean scores of students with different academic disciplines is significant because significance level is less than 0.05, i.e. the students of Humanities, Basic Sciences and Technical Engineering haven't had same opinion about this component. But about self-directed learning, observed difference between mean scores of students is no significant, because, significance level is more than 0.05. Its citable that since difference of means was significant Since this variable is a multi-valued variable, F-test or Analysis Of Variance popularly (ANOVA) will be used.

Table 10. pair comparison of self-direction evaluation of means through student's point of view according to field of study

\begin{tabular}{|c|c|c|l|}
\hline $\begin{array}{c}\text { significance } \\
\text { level }\end{array}$ & $\begin{array}{c}\text { mean } \\
\text { difference }\end{array}$ & Field of study & \multicolumn{1}{c|}{ component } \\
\hline 0.049 & 0.200 & engineering $\leftarrow$ Humanities & $\begin{array}{l}\text { Self-directed } \\
\text { evaluation }\end{array}$ \\
\hline
\end{tabular}

According to Scheffe test, presented in table (10), there is difference between point of view of humanity and Technical Engineering students about self-directed evaluation component. In other words, humanity students suppose their evaluation more self-directed in compare to technical and engineering students. 


\section{Discussion and conclusion}

Is there any relation between self-directed learning and self-directed evaluation of the students?

According to tables ( $6 \&$ 7), there is significant correlation between self-directed learning and self-directed evaluation. In other words there is significant correlation between self-directed learning and self-directed evaluation among Isfahan Azad University students in different fields of study (Humanities, Basic Sciences, engineering). Numerical value of this correlation for 250 students is 0.707 in Pearson test and 0.668 for spearman test that shows a high correlation. Coefficient of determination is 49.98 percent for Pearson test that means 49.98 percent of self-direct evaluation is predicted by self-directed learning. In spearman test coefficient of determination equal to 44.62 which shows that 44.62 percent of self-directed evaluation changes can be stated by self-directed learning, also findings of this research are coordinate With Langendyk(2006), charlotte et al.,(2008), Faey Marshal (2006) and Samadi (2008) findings.

Are these abovementioned relationships based on demographic factors (gender and field of study: Humanities, Basic Sciences, and engineering) different?

According to the results of table (9) about Self-directed learning and Self-directed evaluation, observed difference between mean scores of male and female students is significant, because significance level is less than 0.05, i.e. male and female students haven't had same opinions. Mean score of female students is more than male students mean score. As table (9) shows, about self-directed evaluation, observed difference between mean score of students with different fields of study is significant, significance level is less than 0.05 , because students with different fields of study (Humanities, Basic Sciences and Technical Engineering) haven't had same opinions about self-directed evaluation. But about Self-directed learning, observed difference between mean scores is no significant, because significance level is more than 0.05 . Since about self-directed evaluation, there is difference between mean scores of the students with different fields of study (Humanities, Basic Sciences and engineering), Scheffe post hoc test is used to determine source of difference. According to table (10), about self-directed evaluation, there is difference between humanity and technical student's point of view. In other words, humanity students in compare to the students of Engineering and Technology Group, suppose their evaluation has been more self-directed. Findings of this study are consistent with Samadi (2008) findings.

\section{Practical suggestions:}

In this section regarding two components, practical suggestions will be presented separately and according to findings of this research based on interactive skills, Self-directed learning and Self-directed evaluation relationships, some suggestions will be provided.

\subsection{Self-regulatory learning}

1. Since self-directed learning helps students to succeed, and provides opportunity for them to manage processes same as setting goal, self-control, and self-motivation actively, it is 
suggested that opportunity for development be prepared in above mentioned items.

2. According to positive relationship between Self-directed learning Self-directed and self-directed evaluation, it's recommended to higher Education executives that because of the important effect of self-regulated behaviors on academic progress of the students, notify them about the role of strategies in their academic progress.

3. According to the findings, it is worthy to order faculty members that by providing self-efficacy and Self-directed learning opportunities give their students a better chance of success. Also present courses so that they get part of cognitive structure of students. Teaching metacognitive strategies (self-inquiry, self-monitoring and self-evaluation) for their students they can provide better atmosphere for success.

\subsection{Self-regulatory evaluation}

1. According to positive relationship between interactive skills and self-directed evaluation it is recommended that teachers Help and encourage students to evaluate themselves by correct communication and creating interactive and intimate atmosphere in classroom.

2. According to the important role of self-evaluation in learning it is suggested that university executives run workshop sessions for their professors and students to notify them about necessity and importance of self-evaluation and help them about evaluating themselves.

3. According to the importance of self-directed evaluation it is generally suggested that with taking self-directed evaluation serious, providing incentive policies and promoting a culture of the Self-directed acceptance, to do research on self-directed evaluation of students, proper design and execution of self-evaluation, promote self-directed evaluation .

\section{Acknowledgement}

At the end of all our students who helped in conducting this research, we thank infinitely.

\section{References}

Abedi, Ahmad, H., \& M. Sobhani wide race. (1384). Evaluation of the Elementary Teachers' familiarity with learning theories and how to use them in teaching. Conduct bimonthly Daneshvar, 15, 63-75.

Ahmadvand, M. (1385). Is equal to the active involvement and effective learning: active learning. Teacher Development, 9, 4-7.

Amini, Zrarmhmd. (1387). About their learning strategies - regulatory and motivational beliefs, academic achievement of students. New Thoughts on Education, 4, 136-123.

Amiri, Ali. Naghi. (1383). A comprehensive look at self-control in the organization. management culture magazine, VII, 204-153.

Ao Man- Chih. (2006). The effect of the use of self- regulation learning strategies on college student's performance and satisfaction in physical education, A thesis submitted in partial fulfillment of the requirements of degree doctor of education. 
Bazargan, A. (1388). Educational evaluation, Tehran: samt.

Bembenutty, H. (2008). Self-Regulation of Learning and Academic Delay of Gratification: Gender and Ethnic Differences among College Students. Journal of Advanced Academics, $8(4), 586-616$.

Bembenutty, H. (2008). Self-Regulation of Learning and Academic Delay of Gratification: Gender and Ethnic Differences among College Students. Journal of Advanced Academics, $8(4), 586-616$.

Charlotte Dignath, Gerhard Buettner, \& Hans-Peter Langfeldt. (2008). How can primary school students learn self-regulated learning strategies most effectively? A meta-analysis on self-regulation training programmers. Educational Research Review, In Press, Corrected Proof.

Eternal, MR, and Seif, MH. (1387). Management education, Tehran: Payam Noor University Press.

Faye Marsha G C. (2006). Effects of self-regulated learning on mathematics achievement of selected Southeast Asian Children. Journal of Instructional Psychology.

Fitzpatrick, J L, Sanders, J., \& Worthen, B. (2004). Program Evaluation: Alternative Approaches and Practical Guidances. Boston: Allyn \& Bacon Press.

Gibbs, G., \& Simpson, C (2004). Conditions under which assessment supports Student Learning. Learning and thiching in Higher education, 1(1) , 3-31.

Khadem, M. and Noshad, N. (1385). Examine the relationship between the - with the goal of autoregulation in student learning and achievement - the pre-university students in Shiraz. Shiraz University of Social Sciences and Humanities, IV, 78-63.

Kjbaf, Mohammad Bagher; Hussain Rumi, \& A. Shirazi. (1382). The relationship between motivational beliefs and learning strategies auto regulation of high school students with academic performance. New Journal of Cognitive Science, 1.

Langendyk, V. (2006). Not knowing that they do not know: Self-assessment accuracy of third-year medical students Medical Education, 40, 173-179. Langendyk, V (2006). Not knowing that they do not know: Self-assessment accuracy of third-year medical students. Medical Education, 40, 173-179. http://dx.doi.org/10.1111/j.1365-2929.2005.02372.x

Larnzn, Michael. (2001). Active learning and library instruction, Translated by Fatemeh Hamidi (1383). Journal of the Book, 58, 220-228.

Lawrence, S. et al. (2001). Persistence of Web References in Scientific Research. Computer, 34, 26-31. http://dx.doi.org/10.1109/2.901164

Linen brink, E A, \& Pintrich, P .R. (2002). Motivation as enabler of academic success. school Psychology Review, 31, 313-327.

Nikos M, \& George P. (2005). Student's motivational beliefs, self-regulation strategies use, 
and mathematics achievement. Group for the Psychology of Mathematics Education, 3, 321-328.

P, Robert, \& N. David. (1385). Instruction to improve teaching in universities and higher education centers, Translator: Ahmad Reza Nasr, Hossein Zare and MJ Pakseresht, Isfahan: Isfahan University Press.

Parvin Kadivar. (1380). Investigated the contribution of self-efficacy, self and intelligence in order to offer students a model for optimal learning. Tehran: Institute for education.

Pintrich, PR. (1986). Motivation and learning strategies Interactions with Achievement. Developmental Review, 6. 25-56.

Rhbardar, H. (1384). Patterns of Educational Evaluation and Assessment of Educational Progress exam, Mashhad: Publication of training manuals.

Safavi, Aman Ullah (1387). General teaching methods and techniques. Tehran: Contemporary Publishing.

Samadi, M. (1380). The relationship between metacognitive experience, metacognitive experiences of parents and students and student achievement. New Journal of Cognitive Science, 27-35.

Samadi, M. (1383). Investigated the role of mathematical problem-solving strategies $\neg$ autoregulation in children. Journal of Educational Innovation, 7, 97-79.

Samadi, M. (1387). Study on self-regulated autoregulation $\neg$ Gray Tasyrfvry and educating strategies and mathematical problem solving. Journal of Educational Innovation, 27, 95-79.

Seif, AA (1382). Methods of measurement and evaluation, training. Tehran: Publication period.

Seif, AA. (1386). Psychology, culture. Tehran: Agah Publications.

Shariatmadari, A. (1386). Educational and scientific mission of educational centers in Tehran, the publisher.

Sheikhi, Mehrnoosh. (1383). Evaluated the importance of educational programs. Tavan Journal, 45-42.

Smith, Joe. (1999). One of Volvo's core values. [Online] Available: http://www.volvo.com/environment/index.htm (July 7, 2007).

Solomon race, Akbar Shahrara, \& Mehrnaz. (1380). Locus of control and self-regulatory relationship with academic achievement, Journal of Educational Psychology, 31(2), 175-198.

Srchmy, R., \& Hosseini, SM. (1383). The relationship between learning styles and academic achievement of students in Qazvin. Qazvin University of Medical Sciences Journal, 8(1), 67-64.

Strunk, W., Jr., \& White, E. B. (1979). The elements of style. (3rd ed.). New York: Macmillan, (Chapter 4). 
Van der Geer, J., Hanraads, J. A. J., \& Lupton R. A. (2000). The art of writing a scientific article. Journal of Scientific Communications, 163, 51-59. 